Vol. 3 No. 1 Februari 2019

ISSN 2580-5029

\title{
KEANEKARAGAMAN TUMBUHAN BERKHASIAT OBAT PADA SUKU NOAULU DI PULAU SERAM, MALUKU
}

\author{
Sarmawaty Kotala1, Nirmala Fitria Firdhausi ${ }^{2}$ \\ ${ }^{1}$ IAIN Imam Rijali Ambon, Ambon, Indonesia \\ ${ }^{2}$ UIN Sunan Ampel Surabaya, Surabaya, Indonesia \\ *sharmariyanti@yahoo.com
}

\begin{abstract}
Noaulu an indigenous tribe of Seram Island who live in the Sepa Village of Amahai District, Maluku. This tribe still use forest products to fulfill their needs, including medication. Therefore, this study intends to know the kinds of medicinal plants used by the Noaulu Tribe and the types of diseases that can be treated. Collecting data in this study using survey method and an interview method with the public interest. Determination of the respondents was using purposive sampling method. Inventory of medicinal plants was done by a survey method survey based respondent information. The result of the research shows that there are 31 medicinal plants from 22 families. They are able to cure 20 diseases. The plants which are predominantly used are from Zingiberaceae family. Leaves of the plant are mostly used as the drugs.
\end{abstract}

Keywords: Medicinal Plants, Noaulu Tribe, Village Sepa

\begin{abstract}
ABSTRAK
Suku Noaulu merupakan suku asli Pulau Seram yang tinggal di Desa Sepa Kecamatan Amahai, Maluku. Suku ini masih memanfaatkan hasil hutan untuk memenuhi kebutuhan mereka termasuk pengobatan. Oleh karena itu, penelitian ini bermaksud untuk mengetahui jenis-jenis tumbuhan berkhasiat obat yang digunakan oleh Suku Noaulu dan jenis-jenis penyakit yang dapat diobati. Pengumpulan data pada penelitian ini menggunakan metode survey (jelajah) dan metode wawancara dengan masyarakat Suku Noaulu di Dusun Rohuwa Desa Sepa Kecamatan Amahai Kabupaten Maluku Tengah, Maluku. Penentuan responden dilakukan dengan menggunakan metode purposive sampling. Inventarisasi tumbuhan obat di lapangan dilakukan dengan metode survey lapangan berdasarkan informasi responden. Tumbuhan berkhasiat obat yang digunakan pada masyarakat suku Noaulu di Dusun Rohuwa Desa Sepa sebanyak 31 jenis yang tergolong ke dalam 22 suku (famili) dan mampu mengobati 20 jenis penyakit. Tumbuhan berkhasiat obat yang digunakan didominasi oleh suku Zingiberaceae dan daun merupakan bagian tumbuhan yang sering digunakan untuk pengobatan.
\end{abstract}

Kata Kunci: Tumbuhan Obat, Suku Noaulu, Desa Sepa 
Biotropic 2019 Vol. 3 (1): 49 - 55

Keanekaragaman Tumbuhan Berkhasiat Obat pada Suku Noaulu di Pulau Seram, Maluku

\section{PENDAHULUAN}

Keanekaragaman hayati sangat penting bagi keberlangsungan kehidupan bangsa Indonesia. Hal bukan saja berkaitan dengan posisi Indonesia sebagai salah satu negara terkaya di dunia dalam keanekaragaman hayati, tetapi juga karena keterkaitannya yang erat dengan kekayaan keanekaragaman budaya lokal dan pengetahuan tradisional. Saat ini banyak kekayaan pengetahuan tradisional telah hilang, sejalan dengan terkikisnya budaya tradisional. Penurunan pengetahuan tradisional terjadi karena kurangnya kesadaran akan pentingnya aset karya intelektual, sehingga menyebabkan banyak informasi pengetahuan tradisional belum terdokumentasi dengan baik. Lemahnya dokumentasi dan pesatnya kemajuan di bidang iptek dikhawatirkan secara perlahan tapi pasti akan mendorong punahnya pengetahuan tradisional, dan pada akhirnya akan mempercepat kepunahannya.

Dalam kehidupan sehari-hari masyarakat dapat dilihat adanya keterkaitan antara keanekaragaman hayati dengan sistem-sistem lokal yang berkembang seperti misalnya dalam pemenuhan kebutuhan. Salah satu kebutuhan tersebut contohnya adalah obatobatan yang dapat diperoleh dari hewan maupun tumbuhan. Tumbuhan berkhasiat obat adalah jenis tumbuhan yang pada bagian-bagian tertentu baik akar, batang, kulit, daun maupun hasil ekskresinya dipercaya dapat menyembuhkan atau mengurangi rasa sakit (Falah et al., 2013).

Indonesia diperkirakan memiliki sekitar 370 suku yang hidup di dalam atau sekitar kawasan hutan. Mereka umumnya memiliki pengetahuan tradisional dalam penggunaan tumbuhan berkhasiat obat untuk mengobati penyakit tertentu. Pengetahuan tradisional tentang tumbuhan obat ini kemudian dikembangkan sebagai dasar pengembangan obat fitofarmaka atau obat modern (Supriadi et al., 2001). Salah satu suku yang terdapat di Indonesia adalah Suku Noaulu.

Suku Noaulu adalah suku asli Pulau Seram yang hidup di sekitar atau di dalam hutan Pulau Seram, tepatnya di Kecamatan Amahai, Provinsi Maluku. Suku ini masih memanfaatkan hasil hutan untuk memenuhi kebutuhan mereka termasuk pengobatan. Masyarakat di sekitar kawasan hutan umumnya memiliki pengetahuan lokal dalam pemanfaatan tumbuhan atau bahan alami untuk pengobatan. Pengetahuan mulai dari pengenalan jenis tumbuhan obat, bagian yang digunakan, cara pengolahan sampai dengan khasiat pengobatan merupakan salah satu kekayaan pengetahuan lokal dari suku tersebut.

Pengetahuan lokal Suku Noaulu tentang tumbuhan berkhasiat obat perlu untuk dieksplorasi karena belum diketahui oleh masyarakat lainnya. Berdasarkan paparan di atas, maka perlu dilakukan penelitian untuk mengetahui 
Biotropic 2019 Vol. 3 (1): 49 - 55

Keanekaragaman Tumbuhan Berkhasiat Obat pada Suku Noaulu di Pulau Seram, Maluku

keanekaragaman tumbuhan berkhasiat obat yang digunakan oleh masyarakat Suku Noaulu.

\section{METODE}

Penelitian ini merupakan penelitian deskriptif kualitatif yang bertujuan untuk mengetahui jenis-jenis tumbuhan berkhasiat obat yang digunakan oleh masyarakat Suku Noaulu di Dusun Rohuwa Desa Sepa Kecamatan Amahai, Kabupaten Maluku Tengah, Maluku.

Alat yang digunakan dalam pengambilan data antara lain alat perekam (recorder), kamera, kantong plastik, parang, gunting stek, kertas label, dan kertas koran. Bahan yang digunakan dalam penelitian ini adalah panduan wawancara dan spiritus serta alkohol 70\% sebagai bahan pengawet spesimen tumbuhan obat (Falah et al., 2013).

Pengumpulan data pada penelitian ini menggunakan metode survey (jelajah) dan metode wawancara dengan masyarakat Suku Noaulu di Dusun Rohuwa Desa Sepa Kecamatan Amahai Kabupaten Maluku Tengah, Maluku.

Pengumpulan data dilakukan melalui wawancara dengan responden. Penentuan responden dilakukan dengan menggunakan metode purposive sampling. Tiap responden akan diminta informasi mengenai tumbuhan berkhasiat obat yang selama ini digunakan oleh masyarakat Suku Noaulu. Setiap tumbuhan berkhasiat obat dicatat namanya, bagian yang digunakan, cara penggunaan, dan kegunaannya. Responden yang diwawancarai sebanyak 2 orang dari dukun suku, 15 orang anggota suku dewasa laki-laki dan 15 orang anggota suku dewasa perempuan.

Inventarisasi tumbuhan obat di lapangan dilakukan dengan metode survey lapangan berdasarkan informasi responden. Setiap tumbuhan yang diperoleh difoto dan dicatat karakter morfologinya. Identifikasi tumbuhan berkhasiat obat menggunakan buku-buku identifikasi tumbuhan, seperti: Buku Taksonomi Tumbuhan Obat-Obatan, Kitab Tanaman Obat Nusantara dan AtlasTumbuhan Obat Indonesia. Jenis tumbuhan yang tidak teridentifikasi di lapangan akan diambil untuk dibuatkan herbarium guna identifikasi lebih lanjut. Spesimen herbarium yang telah terkumpul selanjutnya diidentifikasi di Laboratorium MIPA IAIN Ambon. Analisis data dilakukan secara deskriptif kualitatif.

\section{HASIL DAN PEMBAHASAN}

Tumbuhan berkhasiat obat yang digunakan pada masyarakat Suku Noaulu di Dusun Rohuwa Desa Sepa sebanyak 31 jenis yang tergolong ke dalam 22 suku (famili). Jenis-jenis tumbuhan tersebut terdiri dari suku Zingiberaceae (3 jenis), Acanthaceae ( 2 jenis), Arecaceae ( 2 jenis), Rutaceae ( 2 jenis), Lamiaceae ( 2 jenis), Myrtaceae (2 jenis) dan suku-suku lain masing-masing 1 jenis. Hasil selengkapnya dapat dilihat pada Tabel 1. Hasil penelitian tumbuhan berkhasiat obat yang digunakan oleh 
masyarakat Suku Noaulu di Dusun Rohuwa Desa Sepa ditemukan sebanyak 31 jenis yang termasuk ke dalam 22 suku. Suku Zingiberaceae adalah suku dengan jenis tumbuhan terbanyak yang ditemukan dalam penelitian ini. Tumbuhan berkhasiat obat yang digunakan dan termasuk ke dalam Suku Zingiberaceae adalah lengkuas (Alpinia galanga Sw.), kunyit (Curcuma domestica), dan jahe (Zingiber officinale). Bagian tumbuhan yang digunakan oleh Suku Noaulu dari ketiga jenis tumbuhan tersebut adalah rimpang.

Di Indonesia rimpang lengkuas $(A$. galanga Sw.) digunakan untuk mengobati panu dan mengandung minyak atsiri, resin yang disebut galangol, zat kristalin berwarna kuning yang disebut kaempferid dan golangin (Tjitrosoepomo, 2005). Selain mengobati panu, masyarakat Suku Noaulu juga menggunakan lengkuas untuk mengobati penyakit kudis. Kunyit (C. domestica) memiliki rimpang induk dan rimpang anakan. Oleh masyarakat Suku Noaulu rimpang induk kunyit digunakan untuk mengobati penyakit batuk, sedangkan rimpang anakannya digunakan untuk mengobati pegal-pegal. Rimpang tersebut mengandung 5\% minyak atsiri, kurkumin, resin, amilum (Preetha et al., 2016). Kandungan kurkumin berkhasiat sebagai antibakteri, antioksidan, dan antihepatotoksoid (Mangonting, 2008). Manfaat pengobatan yang dapat diperoleh dari rimpang jehe (Z. officinale) hampir sama dengan kunyit kerena jahe mengandung minyak atsiri 1-3\%, zingiberon, resin, dan tepung (Tjitrosoepomo, 2005).

Sambiloto (Andrographis paniculata) yang digunakan untuk mengobati pegalpegal dan daun wungu (Graptophyllum pictum) untuk mengobati bisul termasuk dalam suku Acanthaceae. Daun wungu mengandung glikosida, steroid, alkaloid, saponin, tanin, dan lendir (Jiangseubchatveera et al., 2017). Sambiloto mengandung laktone, flavonoid, alkane, keton, aldehid, mineral (kalium, kalsium, natrium), asam kersik, dan damar (Dalimartha, 1999; Jooselin \& Jeeva, 2014).

Tabel 1. Tumbuhan berkhasiat obat yang digunakan oleh masyarakat Suku Noaulu di Dusun Rohuwa Desa Sepa

\begin{tabular}{|c|c|c|c|c|c|}
\hline No & $\begin{array}{c}\text { Nama Tumbuhan } \\
\text { dan Bagian yang } \\
\text { Digunakan }\end{array}$ & Suku (Famili) & No & Nama Tumbuhan & Suku (Famili) \\
\hline 1. & $\begin{array}{l}\text { Alpinia galanga(lengkuas, } \\
\text { rimpang) }\end{array}$ & Zingiberaceae & 17. & $\begin{array}{l}\text { Carica papaya (pepaya, } \\
\text { daun) }\end{array}$ & Caricaceae \\
\hline 2. & $\begin{array}{l}\text { Alstonia scholaris (pohon } \\
\text { pule, kulit batang) }\end{array}$ & Apocynaceae & 18. & $\begin{array}{l}\text { Citrus } \\
\text { aurantifolia(jeruk nipis, } \\
\text { buah) }\end{array}$ & Rutaceae \\
\hline 3. & $\begin{array}{l}\text { Andrographis paniculata } \\
\text { (sambiloto, daun dan } \\
\text { batang) }\end{array}$ & Acanthaceae & 19. & $\begin{array}{l}\text { Citrus microcarpa } \\
\text { (lemon cina, daun dan } \\
\text { buah) }\end{array}$ & Rutaceae \\
\hline 4. & $\begin{array}{l}\text { Annona muricata(sirsak, } \\
\text { daun) }\end{array}$ & Annonaceae & 20. & $\begin{array}{l}\text { Coleus } \\
\text { atropurpureus(miana/il }\end{array}$ & Lamiaceae \\
\hline
\end{tabular}


Biotropic 2019 Vol. 3 (1): 49 - 55

Keanekaragaman Tumbuhan Berkhasiat Obat pada Suku Noaulu di Pulau Seram, Maluku

er, daun dan batang)

\begin{tabular}{|c|c|c|c|c|c|}
\hline No & $\begin{array}{c}\text { Nama Tumbuhan } \\
\text { dan Bagian yang } \\
\text { Digunakan }\end{array}$ & Suku (Famili) & No & Nama Tumbuhan & Suku (Famili) \\
\hline 5. & Areca catechu (pinang, biji) & Arecaceae & 21. & $\begin{array}{l}\text { Curcuma longa(kunyit, } \\
\text { rimpang) }\end{array}$ & Zingiberaceae \\
\hline 6. & $\begin{array}{l}\text { Artocarpus communis } \\
\text { (sukun, daun kuning) }\end{array}$ & Moraceae & 22. & $\begin{array}{l}\text { Crinum } \\
\text { asiaticum(bakung, } \\
\text { umbi akar) }\end{array}$ & Amaryllidaceae \\
\hline 7. & $\begin{array}{l}\text { Calophyllum } \\
\text { inophylum(Bintangor, pucuk } \\
\text { daun muda) }\end{array}$ & Clusiaceae & 23. & $\begin{array}{l}\text { Cymbopogon citratus } \\
\text { (sereh, daun) }\end{array}$ & Poaceae \\
\hline 8. & $\begin{array}{l}\text { Graptophyllum } \\
\text { pictum(alifuru/daun wungu, } \\
\text { daun) }\end{array}$ & Acanthaceae & 24. & $\begin{array}{l}\text { Phyllanthus urinaria } \\
\text { (meniran, daun dan } \\
\text { batang) }\end{array}$ & Phyllanthaceae \\
\hline 9. & $\begin{array}{l}\text { Gynura procumbens } \\
\text { (sambung nyawa, daun) }\end{array}$ & Asteraceae & 25. & $\begin{array}{l}\text { Piper betle (sirih, buah } \\
\text { dan daun) }\end{array}$ & Piperaceae \\
\hline 10. & $\begin{array}{l}\text { Jatropha curcas (jarak pagar, } \\
\text { daun) }\end{array}$ & Euphorbiaceae & 26. & $\begin{array}{l}\text { Psidium guajava (jambu } \\
\text { biji, daun) }\end{array}$ & Myrtaceae \\
\hline 11. & $\begin{array}{l}\text { Laportea decumana (daun } \\
\text { gatal, daun) }\end{array}$ & Urticaceae & 27. & $\begin{array}{l}\text { Sauropus } \\
\text { androgynus(katuk, } \\
\text { daun) }\end{array}$ & Phyllanthaceae \\
\hline 12. & Metroxylon sagu (sagu, pati) & Arecaceae & 28. & $\begin{array}{l}\text { Sesbania grandiflora } \\
\text { (turi, daun) }\end{array}$ & Fabaceae \\
\hline 13. & $\begin{array}{l}\text { Morinda citrifolia } \\
\text { (mengkudu, buah) }\end{array}$ & Rubiaceae & 29. & $\begin{array}{l}\text { Syzygium aromaticum } \\
\text { (cengkeh, bunga) }\end{array}$ & Myrtaceae \\
\hline 14. & $\begin{array}{l}\text { Moringa oleifera (kelor, kulit } \\
\text { batang, daun) }\end{array}$ & Moringaceae & 30. & $\begin{array}{l}\text { Terminalia } \\
\text { catappa (ketapang, } \\
\text { akar) }\end{array}$ & Combretaceae \\
\hline 15. & Myristica fragrans(pala, biji) & Myristicaceae & 31. & $\begin{array}{l}\text { Zingiber officinale (jahe, } \\
\text { rimpang) }\end{array}$ & Zingiberaceae \\
\hline 16. & $\begin{array}{l}\text { Orthosiphon arista } \\
\text { tus (kumis kucing, daun dan } \\
\text { batang) }\end{array}$ & Lamiaceae & & & \\
\hline
\end{tabular}

Sumber: Data Hasil Penelitian 2017

Dua jenis tumbuhan yang digunakan sebagai obat oleh Suku Noaulu termasuk ke dalam suku Arecaceae, yaitu pinang (Areca catechu) dan sagu (Metroxylon sagu Rottb.). Pinang digunakan sebagai obat bersama dengan sirih (Piper betle) untuk mengobati maag, diabetes, dan sakit gigi, sedangkan sagu digunakan sebagai obat demam, cacar air, dan batuk darah. Selain itu, sagu juga merupakan salah satu makanan pokok di Maluku dan Papua.

Biji pinang mengandung alkaloid yang disebut arekoline, arekaidin, juvasine, juvakoline, arekolidin, senyawa tanin, dan lemak (Tjitrosoepomo, 2005), sedangkan daun sirih. mengandung minyak atsiri kavikol dan kavibetol yang bersifat anti kuman (Dewi et al., 2015). Daun sirih juga digunakan oleh Suku Noaulu untuk menghentikan darah pada luka.

Masing-masing dua tumbuhan obat yang digunakan oleh Suku Noaulu termasuk ke dalam suku Rutaceae, Lamiaceae, dan Myrtaceae. Suku Rutaceae atau suku jerukjerukkan yang digunakan terdiri dari jeruk nipis (Citrus aurantifolia) dan lemon cina 
(Citrus microcarpa), suku Lamiaceae terdiri atas daun miana (Coleus atropurpureus)dan kumis kucing (Orthosiphon aristatus), sedangkan suku Myrtaceae terdiri atas jambu biji (Psidium guajava) dan cengkeh (Syzygium aromaticum (L.) Merril \& Perry).

Bagian tumbuhan yang digunakan sebagai obat dari jeruk nipis (C. aurantifolia) adalah air jeruk yang dihasilkan oleh buahnya, sedangkan dari lemon cina (C. microcarpa) adalah bagian daun dan air perasan dari buahnya. Air perasan jeruk nipis mengandung vitamin $C$, kalsium, fosfor, hidrat arang, vitamin B1, zat besi, lemak, protein, dan air (Enejoh et al., 2015), sedangkan lemon cina mengandung vitamin C.

Daun miana (C. atropurpureus) dan kumis kucing (O. aristatus) digunakan oleh masyarakat Suku Noaulu untuk mengobati penyakit TBC. Daun miana mengandung alkaloid, etil salisilat, metil eugenol, timol, karvakrol, mineral, minyak atsiri, dan tanin, sedangkan kumis kucing mengandung orthosiphon glikosida, zat samak, minyak atsiri, minyak lemak, saponin, sapofonin, garam kalium, dan myoinositol (Verawati et al., 2016).

Bagian tumbuhan yang digunakan sebagai obat oleh Suku Noaulu terdiri atas berbagai macam. Satu atau beberapa bagian dari satu jenis tumbuhan dapat digunakan sebagai obat. Beberapa bagian dari satu jenis tumbuhan dapat mengobati penyakit yang sama maupun penyakit yang berbeda. Bagian tumbuhan yang digunakan sebagai obat terdiri dari 10 bagian, yaitu: akar, batang, kulit batang, daun, buah, rimpang, bunga, biji, umbi, dan pati.

Pada tumbuhan berkhasiat obat yang digunakan oleh suku Noaulu terdapat beberapa jenis tumbuhan obat yang penggunannya masih belum diketahui oleh masyarakat luas. Jenis-jenis tumbuhan tersebut adalah Callophylum inophylum L., Crinum asiaticum L., Sesbania grandiflora, dan Laportea decumana. Khusus untuk tumbuhan Laportea decumana telah lama dikenal sebagai tumbuhan obat yang sering digunakan oleh masyarakat asli Maluku dan Papua.

\section{KESIMPULAN}

Tumbuhan berkhasiat obat yang digunakan oleh Suku Noaulu di Dusun Rohuwa Desa Sepa adalah sebanyak 31 jenis tumbuhan yang tergolong ke dalam 22 suku (famili). Jenis-jenis tumbuhan tersebut adalah Alpinia galanga Sw, Alstonia scholaris, Andrographis paniculata, Annona muricata L., Areca catechu L., Artocarpus communis, Calophyllum inophylum L., Carica papaya L., Citrus aurantifolia, Citrus microcarpa, Coleus atropurpureus (L.) Benth., Curcuma longa Linn., Crinum asiaticum L., Cymbopogon citratus, Graptophyllum pictum, Gynura procumbens (Blume) Miq., Jatropha curcas L., Laportea decumana, Metroxylon sagu Rottb., Morinda citrifolia, Moringa oleifera,Myristica fragrans, Orthosiphon arista, Phyllanthus urinaria, Piper betle L., Psidium guajava, 
Sauropus androgynus, Sesbania grandiflora,

Syzygium aromaticum, Terminalia catappa, dan Zingiber officinale.

\section{DAFTAR PUSTAKA}

Dalimartha, S. 1999. Atlas Tumbuhan Obat Indonesia Jilid 1. Trubus Agriwidia, Jakarta.

Dewi, SR., Nugroho, WA., Hendrawan Y., \& Nissa, K. 2015. Karakterisasi ekstrak Etanolik Daun Sirih Merah (Piper crocatum). Prosiding seminar Nasional perteta, Makassar.

Enejoh, OS., Ogunyemi, IO., Bala, MS., Oruene, IS., Suleiman, MM., \& Ambali, S.F. 2015. Ethnomedical Importance of Citrus aurantifolia (Chirstm) Swingle. The Pharma Innovation Journal. 4 (8): 01 - 06.

Falah, F., Sayektiningsih, T., \&Noorcahyanti, N. 2013. Keragaman Jenis dan Pemanfaatan Tumbuhan Berkhasiat Obat oleh Masyarakat Sekitar Hutan Lindung Gunung Beratus, Kalimantan Timur. Jurnal Penelitian Hutan dan Konservasi Alam .

Joselin J. \& Jeeva S. 2014. Andrographis paniculata: A Review of its Traditional Uses, Phytochemistry and Pharmacology. Medicinal dan Aromatic Plants, 3:4.

Jiangseubchatveera, N., Liawruangrath, S., Teerawutgulrag, A., Santiarworn, D., \& Pyne, SG. 2017. Phytochemical Screening, Phenolic and Flavonoid Contents, Antioxidant and Cytotoxic Activities of Graptophyllum pictum (L.) Grif. Journal of Science. 44(1): 193 $-202$.

Mangonting, D., Irawan, I., \& Abdullah, S. 2008. Tanaman Lalap Berkhasiat Obat. Penebar Swadaya, Jakarta

Preetha, TS., Sudarsanan, S., Khrisnan, \& PN. 2016. A Comprehensive Review of Kaempferia galanga L.
(Zingiberaceae): A High Sought Medicinal Plant in Tropical Asia. Journal of Medicinal Plants Studies. 4(3): 270 - 276.

Supriadi. 2001. Tumbuhan Obat Indonesia: Penggunaan dan Khasiatny. Pustaka Populer Obor, Jakarta.

Tjitrosoepomo, G. 2005. Taksonomi Tumbuhan Obat-obatan. Gadjah Mada University Press, Yogyakarta.

Verawati, Aria, M., Dira, Maisa, S., \& Maharani, A. 2016. Chemical Characterization and AntiInflammatory activity of Piladang Leaf (Coleus atropurpureus) Extract. Journal of Chemical and Pharmaceutical Sciences. 9(4). 